\title{
IMPLIKASI TEORI PUNISHMENT PENDIDIKAN ISLAM DALAM PERSPEKTIF HAK ASASI MANUSIA
}

\author{
Zulfikar Ali Buto \\ STAIN Malikussaleh Lhokseumawe \\ Email: zaule_lsm@yahoo.com
}

\section{Abstract}

This paper describes the theory of punishment in Islamic education. Punisbment in education is two sides of a coin that cannot be separated. Punishment is needed as implementation of regulations that are expected to acbieve the vision and mission of education. It should be a concem that punishment in education as a means of implementation of the learning process can provide the future success of students. In this case, the punishment is not contraty to buman rights as long as intended for goodness.

\section{مستخفلص}

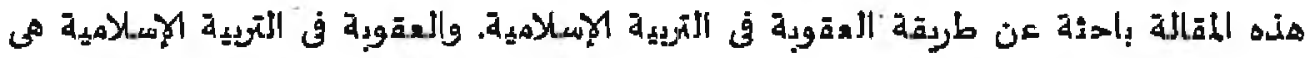

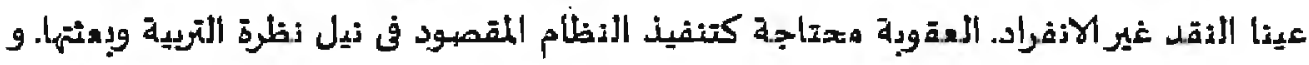

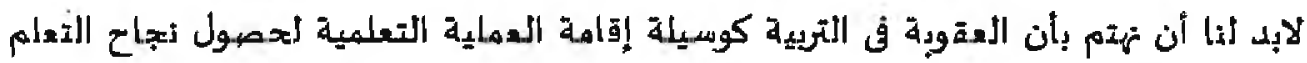

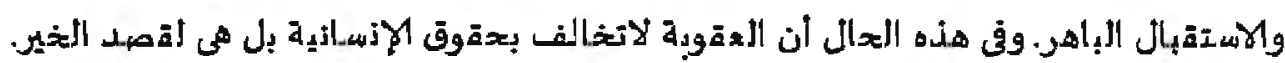
Keywords: Punishment, Pendidikan Islam, Hak Asasi Manusia.

\section{A. Pendahuluan}

Persepsi punishment dalam dunia pendidikan akhir-akhir ini menjadi sorotan publik yang maha dahsyad. Punishment dipahami sebagai tinta hitam yang harus dibumihanguskan (dihilangkan) dengan berbagai alasan apapun. punishment dinilai sebagai upaya pembunuhan karekter anak, punishment dinilai sebagai 
pelanggaran hak asasi anak dan punishment dinilai sebagai peluang pelampisan balas dendam baik guru maupun orang tua. Teori Pendidikan Islam meberikan gambaran bahwa Punishment dalam dunia pendidikan merupakan hal yang wajar dan dipandang perlu diberlakukan, refleksinya adalah punishment dilakukan untuk meminimalisir pelanggran dan memberi efek jera terhadap pelaku sehingga tidak mengulangi kembali kesalahan yang telah bertengger dalam dirinya dengan tahap-tahap yang. benar.

Dunia pendidikan merupakan dunia akademik, dunia tanpa batas usia, dunia tanpa pandang bulu. Dunia pendidikan memiliki cakupan yang sangat luas, cakupan ini barlaku untuk semua tingkatan usia manusia tanpa terkeculai bagi yang sudah lahir maupun yang belum lahir. Pendidikan didefinisikan sebagai proses pendewasaan fisik, proses pendewasaan jiwa, pendewasaan perilaku, pendewasaan sosial. Proses pendidikan yang dijalani manusia perlu stimulus yang mengarahkan mereka pada jalan serta bekal menuju pendewasaan tersebut. Proses pendidikan memberi sirkulasi kehidupan bagi manusia, sirkulasi ini dapat diartikan sebagai celah untuk memilih atau menentukan pilihan yang harus dan cocok untuk ditempuh. Penentuan pilihan yang salah memberi efek negatif, alhasil sedikit banyaknya mengalami keguguran di tengah perjalanan hidup yang penuh dengan sejuta onak dan duri serta kerikil tajam kerap menghujam alunan langkah kaki manusia.

Lembaga pendidikan kini menjadi mati kutu dengan berbagai statement filosofi hak asasi manusia dan rumusan-rumusan undang-undang yang mengarah pada hak asasi manusia. Dunia akademik tentu memiliki nilai serta aturan main sendiri dalam memberikan pengalaman hidup bagi generasi umat berikutnya terlebih dalam pemberian hukuman dalam konteks pendidikan. Lembaga pendidikan yang notabenenya adalah pelaksana operasional peserta didik pasti sudah banyak makan garam dan tahu précis apa yang harus dilakukan pada anak didiknya. Berbeda halnya dengan perumusan undang-undang ant kekerasan apalagi proses tersebut dilakukan di balik gedung bertingkat tanpa mempertimbangkan nilai operasional yang kerap sekali tidak sesuai dengan perkiraan sebelumnya. 
Berbagai ulasan $\mathrm{di}$ atas penulis ingin menegahkan teori punishment pendidikan Islam dengan menganalisisnya pada nilai-nilai hak asasi manusia. Pertimbangan ini perlu dilakukan kembali ditengahkan khususnya bagi pelaksana pendidikan di lapangan dengan harapan bahwa apakah dewasa ini punishment masih diperlukan di dunia pendidikan, lalu bagaimana dengan undang-undang hak asasi manusia.

\section{B. Pengertian Punishment}

Punishment (hukuman) adalah penyajian stimulus yang tidak menyenangkan untuk menghilangkan perilaku anak yang tidak diharapkan, punishment dapat pula diartikan suatu bentuk sanksi yang diberikan pada anak baik sanksi fisik maupun psikis ketika, anak melakukan kesalahan-kesalahan atau pelanggatan yang sengaja dilakukan terhadap peraturan-peraturan yang telah ditetapkan.

Menurut Fauzan dalam tesisnya menyebutkan bahwa secara etimologis kata hukuman berasal dari kata hukum yang artinya "peraturan yang dibuat oleh sesuatu kekuasaan atau adat yang dianggap berlaku oleh dan untuk orang banyak atau undang-undang (peraturan) dan sebagainya untuk mengatur pergaulan hidup dalam bermasyarakat."2 Dalam bahasa Inggris, punishment diantonimkan dengan reward. Sedangkan menurut terminologis, pengertian punishment dapat didefinisikan sebagai "suatu perbuatan dimana seseorang secara sadar dan sengaja menjatuhkan nestapa kepada orang lain dengan tujuan memperbaiki atau melindungi dirinya dari kelemahan jasmani dan rohani, sehingga terhindar dari segala macam pelanggaran."3 Punishment juga bermakna sebagai suatu tindakan yang dijatuhkan kepada anak secara sadar dan sengaja sehingga menimbulkan nestapa dan dengan adanya nestapa itu, anak akan

1Depdikbud, Metodik Kbusus Program Pemberukan Perilaku di Taman Kanak-kanak, Jakarta: Gramedia Widiasarana Indonesia, 1998), hal. 47.

${ }^{2}$ Abdullah Ali, Kamus Istilah, (Jakarta: Pustaka, 1985), hal. 67.

${ }^{3}$ M. Sastrapraja, Kamus Istilab Pendidikan dan Umum untuk Guru, Calon Guru dan Umum, (Surabaya: Usaha Nasional, t.t), hal. 201. 
menjadi sadar akan perbuatannya dan berjanji di dalam hatinya untuk tidak mengulanginya. ${ }^{4}$

Menurut Langeveld pumishment adalah perbuatan yang dilakukan dengan sadar dan sengaja sehingga menyebabkan penderitaan pada seseorang yang biasanya lebih lemah (jasmaniah dan rohaniahnya) dan dipercayakan pada pendidik untuk diasuh dan dilindungi dan hukuman itu memang dimaksudkan agar anak didik benar-benar merasakannya. ${ }^{5}$

Jelas bahwa punishment dalam dunia pendidikan dibutuhkan dalam menginternaliasikan nilai-nilai kependidikan yang ada. Kondisi ini tidak ubahnya dibaratkan pada proses pelaksanaan kedisiplinan akan sulit diaplikasikan tanpa adanya unsur pemaksaan. Pemaksaan ini diartikan dalam arti luas bahwa berjalannya sesuatu yang sudah disepakati akan sulit terpenuhi bila tidak dibarengi dengan tuntutan yang kuat melalui stimulus dan lainnya. Pemberian stimulus dapat berupa punishment atau hukuman yang dapat memberikan aroma penyedap kedisiplinan anak, konon hal tersebut untuk membiasakan anak untuk berbuat kebaikan. Walau punisbment adakalanya memberi dampak negatif pada anak, untuk itu para pendidik yang memberikan punisbment harus dapat memilih bentuk-bentuk punishment yang sesuai dengan usia dan kadar kesalahan anak didiknya.

Fauzan mengatakan bahwa pemberian hukuman dimaksudkan agar subyek didik menjadi baik dan berhasil dalam pendidikannya. Mengubah dari kebisaaan buruk menjadi baik, mengubah dari kebisaan salah menjadi benar, memperbaiki dari yang banyak melanggar menjadi patuh, serta meminimalisir pelanggatan anak di lingkungan sekolah. Untuk itu pemberian hukuman harus dilandasi pada beberapa syarat, yaitu:

a. Pemberian hukuman harus tetap dalam jalinan cinta kasih sayang.

b. Pemberian hukuman harus didasarkan pada alasan "keharusan"

c. Pemberian hukuman harus menimbulkan kesan pada hati anak

4Harianto AJ, Pembinaan Pengurus Asrama Santri; Sebrab Proses Kaderisasi Kepemimpinan di Pondok Modem Gantor, (Gontor. t.p., 1992), hal. 43.

${ }^{5}$ M. J. Langeveld, Beknotpte theonetische Paedagogik, Terjemahan I.P. Simanjuntak, (Jakarta: Senat Mahasiswa Fakultas Ilmu Pendidikan IKIP, tt), hal. 120. 
d. Pemberian hukuman harus menimbulkan keinsyafan dan penyesalan pada anak

e. Pada akhinya, pemberian hukuman harus diikuti dengan pemberian ampun dan disertai dengan harapan serta kepercayaan. ${ }^{6}$

\section{Teori Punishment Pendidikan Islam}

Pendidikan Islam meberikan perspektif tersendiri dalam mendefinisikan punishment atau hukuman. Punishmenti dalam bahasa Arab diartikan sebagai, al'uqubah, iqab dan al-qishas. ${ }^{7}$ Kalimat iqab banyak digunakan Allah swt dalam konteks perlakuan tidak menyenangkan yang akan ditimpakan kepada siapa saja yang melakukan perbuatan yang tidak baik atau tercela. Dalam surat al-Anfal ayat 52 dan surat al-maidah ayat 2 Allah swt. berfirman:

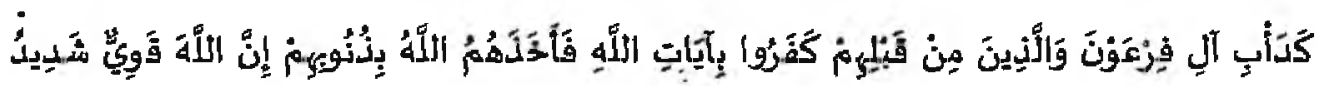

$$
\text { الْجِةًابِ (or) }
$$

"(keadaan mereka) serupa dengan keadaan Fir'aun dan pengikut-pengikutnya serta orang-orang yang sebelumnya metcka mengingkari ayat-ayat Allah, maka Allah menyiksa mereka disebabkan dosa-dosanya. Sesungguhnya Allah Maha Kuat lagi amat keras siksaan-Nya". (Al-Anfal; 52).

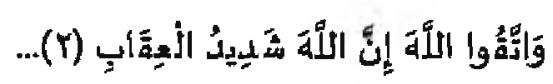

“...dan bertakwalah kamu kepada Allah, sesungguhnya Allah sangat pedih siksanya."(Al-Maidah:2).

Ayat-ayat di atas memberikan insfirasi tersendiri bagi kita selaku hamba Allah yang sering memberikan hukuman bagi peserta didik di lingkungan pendidikan. Ayat tersebut menjelaskan bahwa setiap pemberian hukuman diharuskan untuk memberikan nuansa yang menyenangkan bagi yang bermasalah. Hal ini dibutuhkan agar pemberi hukuman tidak serta merta memberikan hal-hal di luar batas-batas nilai hukuman yang mendidik.

'Fauzan, Penerapan Hukuman Fisik Pada Dayab Syamsyuddhuba Cot Mamng Kabupaten Aceb Utara, (Medan: Tesis IAIN Medan Sumatera Utara, 2011), hal. 30.

7A.W. Munawwir, Kamus al-Mmanvir Arab-Indonesia Terlengkep, Edisi Lux, (T.t.p: t.p, t.t.), hal 1022. 
Pemberian hukuman dalam pendidikan Islam, hukuman pada dasamya adalah instrumen untuk: pertama, memelihara fitrah peserta didik agar tetap suci, bersih dan bersyahadah kepada Allah swt. Kedua, membina kepribadian peserta didik agar tetap istiqamah dalam berbuat kebajikan dan berakhlak mulia dalam setiap perilaku atau tindakan. Ketiga, memperbaiki diri peserta didik dari berbagai sifat dan amal tidak terpuji yang telah dilakukannya, baik dipandang dari perspektif agama maupun nilai dan norma yang berlaku dalam suatu masyarakat. Ibn Sina mengatakan bahwa pemberian hukuman harus dengan cata ekstra hati-hati, dan hal itu hanya boleh dilakukan dalam keadaan terpaksa atau kurang normal dari biasanya. Sikap inilah yang disejalankan dengan alam sosial yang dipandang adil dan manusiawi. ${ }^{8}$

Menurut Rasyidin dalam teșis Fauzan (2011) mengungkapkan pemberian hukuman harus dilakukan dalam beberapa aturan main yaitu sebagai betikut:

1. Jangan sekali-kali menghukum sebelum pendidik berusaha sungguhsungguh melatih, mendidik, dan membimbing anak didiknya dengan pengetahuan, keterampilan, dan sikap mental yang baik. Allah sendiri tidak pernah menghukum hamba-Nya sebelum Ia memberikan pendidikan bagi mereka, baik dengan mendidik secara langsung melalui rasul-Nya, dan dengan menurunkan Alquran.

2. Hukuman tidak boleh dijalankan sebelum pendidik menginformasikan atau menjelaskan konsekuensi logis dari suatu perbuatan. Dalam Alquran, Allah swt. selalu menjelaskan jika manusia memilih jalan kesesatan, maka mereka akan sengsara, akan ditimpa kehinaan, atau akan dimasukkan ke dalam neraka. Sebaliknya jika manusia menempuh jalan yang lurus, maka mereka akan beroleh petunjuk, kebahagiaan atau dimasukkan ke dalam surga.

3. Anak tidak boleh dihukum sebelúm pendidik memberi peringatan pada mereka. Pemberian peringatan ini didasarkan pada contoh yang terdapat dalam Alquran surat ail-Baqarah ayat 35-36 di mana Allah swt. menghukum Adam dan Hawa dengan mencampakkan mereka ke bumi setelah terlebih dahulu Dia memperingatkan keduanya.

BIbn Sina, "Tis'u Rasail", dalam Abuddin Nata, Pemikiran Para Tokob Pendidilean Islam, (Jakarta: Raja Grafindo Persada, 2001), hal. 79. 
4. Tidak dibenarkan menghukum anak sebelum, pendidik berusaha secara sungguh-sungguh' membiasakan mereka dengan perilaku yang terpuji.

5. Hukuman belum boleh digunakan sebelum pendidik memberi kesempatan pada anak didiknya untuk memperbaiki diri dari kesalahan yang telah dilakukannya.

6. Sebelum memutuskan untuk menghukum, pendidik hendaknya berupaya menggunakan mediator untuk menasehati atau merubah perilaku peserta didik. Mediator tersebut haruslah merupakan significant persons, yakni orangorang yang memiliki akses dan pengaruh besar dalam kehidupan material, psikologis, dan spiritual peserta didik. Bukankah Allah swt. tidak akan menghukum suatu kaum, sebelum kepada mereka diutus seorang rasul??

Lukman bin Ma'sa mengemukakan bahwa ada lima prinsip yang harus diperhatikan oleh seorang pendidik dalam menerapkan hukuman terhadap anak didik. Pertama, kepercayaan terlebih dahulu kemudian hukuman, Kedua, hukuman distandarkan pada prilaku, Ketiga, menghukum tanpa emosi. Keempat, hukuman sudah disepakati. Kelima, tahapan pemberian hukuman. Dalam memberikan hukuman tentu harus melalui beberapa tahapan, mulai yang teringan hingga akhirnya yang terberat. ${ }^{\text {to }}$

Berikut macam-macam hukuman yang teraplikasi dilapangan sebagai tolak ukur bagi para pendidik untuk memberikan hukuman jika diperlukan dalam dunia akademik sebagai berikut:

1. Hukuman alam. Teori hukuman alam ini dikemukakan oleh penganjur pendidikan alam, yaitu J.J. Rousseau. Rousseau tidak menghendaki hukuman yang dibuat-buat. Biarlah alam sendiri yang menghukumnya. Yang dimaksud di sini ialah bahwa hukurnan itu merupakan akibat yang sewajarnya dari suatu perbuatan. Hukuman harus merupakan suatu yang natur menurut hukum-hukum alam, sesuatu akibat logis yang tidak dibuatbuat. Biarlah alam yang menghukum:anak itu sehingga pada akhinnya anak

9Al Rasyidin, Falsafab Pendiditan Islami; Membangan Kerangken Ontologi, Epistimologi.dan Aksiologi Praktik Pendidikan, (Bandung: Citapustaka, 2008), hal. 101-102.

${ }^{10}$ Lukman bin Ma'sa, "Konsep Penghargaan dan Sanksi dalam pendidikan Islam (Studi Kasus Pendidikan pada Anak)", dikutip dari http://www. Googlecom, diakses 13 Maret 2012. 
merasakan sendiri akibat yang sewajarnya dari perbuatannya itu nantinya anak itu akan insaf dengan sendirinya. Misalnya anak yang senang berlari-lati di tangga adalah wajar dan logis apabila suatu ketika ia jatuh. Jatuh ini merupakan hukuman menurut alam sebagai akibat dari perbuatannya. Hukuman ini menurut hemat penulis sangat berbahaya dan beresiko tinggi. dan akibat yang diterima oleh sianakpun lebih fatal, terutama bagi anak yang masih kecil.

2. Hukuman badan/jasmani. Hukuman jenis ini memberi akibat yang merugikan si anak dan bahkan dapat menimbulkan gangguan kesehatan bagi anak. Misalnya guru menangkap basah anak didik sedang merokok, maka anak dihukum dengan keharusan merokok terus menerus selama waktu sekolah, ini bisa berakibat anak batuk atau pusing dan sakit.

3. Hukuman Balas Dendam. Hukuman yang paling jelek, yang paling jahat, dan paling tidak dapat dipertanggung jawabkan dalam dunia pendidikan adalah hukuman yang didasarkan pada rasa sentimen yang ditimbulkan oleh suatu kekecewaan. Hukuman ini diberikan untuk melampiaskan kemarahan dan kekecewaan tersebut, dan karena pendidik tidak senang anak berbuat salah sehinggga baru merasa puas setelah anak yang berbuat salah dihukum. Hukuman semacam ini berdampak negatif karena akan menimbulkan keretakan hubungan antara pendidik dan anak didik.

4. Hukuman jeruk manis. Menurut tokoh yang mengemukakan teori hukuman ini, Jan Lighart, anak yang nakal tak perlu dihukum, tetapi didekati dan diambil hatinya. Apabila anak berbuat kesalahan atau melanggar peraturan maka guru petlu. melakukan upaya pendekatan dengan anak didik. Mengupayakan berlaku baik dar memberikan perhatian kepada anak untuk mengambil hatinya sehingga ia akan berubah karena merasa malu atau sayang terhadap guru.

5. Hukuman Memperbaiki. Hukuman jenis ini dijatuhkan dengan tujuan agar anak mau memperbaiki kesalahannya. Kesalahan itu akan diperbaiki oleh anak, bilamana si anak telah mengetahui kesalahannya, mengakui 
kesalahannya yang telah dilakukan dan baru memungkinkan. si anak memperbaikinya. ${ }^{11}$

\section{Pertautan dengan Hak Asasi Manusia}

Diskriminasi seorang anak terkadang memberikan pemahaman yang bermacam-macam. Diskriminasi sering dipahami dengan kekerasan yang memberi efek besat bagi objek pelaku. Rumusan Undang-Undang HAM tercatat bahwa hak anak dalam Pasal 58 Bagian kesepuluh Ayat 1 dan 2 manyatakan bahwa (1) Setiap anak berhak untuk mendapatkan perlindungan hukum dari segala bentuk kekerasan fisik atau mental, penelantaran, perlakuan buruk, dan pelecehan seksual selama dalam pengasuhan orang tua atau walinya, atau pihak lain maupun yang bertanggung jawab atas pengasuh anak tersebut. (2) Dalam hal orang tua, wali, atau pengasuh anak melakukan segala bentuk penganiayaan fisik atau mental, penelantaran, perlakuan buruk, dan pelecehan seksual termasuk pemerkosaan, dan atau pembunuhan terhadap anak yang seharusnya dilindungi, maka häus dikenakan pemberatan hukuman. ${ }^{12}$

Demikian halnya dengan hak perlindungan anak, Negara Republik Indonesia memiliki undang-undang perlindungan anak yang jelas, namun di samping itu negera juga belum memikirkan sanksi positif bagi anak yang melanggar hukum. Hal ini menjadi cukup bias dikala pelangaran yang dilakukan di bawa keranah hukum. Dunia pendidikan khususnya memiliki catatan pelanggaran hukum yang dinilai kriminal oleh undang-undang negara akan tetapi tempat kejadiannya di lembaga pendidikan dan masih dalam proses pendidikan berlangsung. Sehingga hal ini menjadi mempersempit ruang gerak guru yang ingin melakukan pembenahan dan perubahan yang baik pada diri peserta didiknya.

Undang-Undang Perlindungan Anak, pasal 48, bagian tiga, pemerintah wajib menyelenggarakan pendidikan dasar minimal 9 (sembilan) tahun untuk

"Fauzan, Pemberian Hukuman Fïsik..., hal. 65

12Anonym, "UU No. 391999 Tentang. HAM", dikutip dari www.bookfinder.com/dir/i/Undang-Undang_HAM_1999-UU_RI_No_39 ditunduh 18 Maret 2012 . 
semua anak. Dilanjutkan pada pasal berikutnya pada pasal 50 dijelaskan pengembangan rasa hormat terhadap orang tua, identitas budaya, bahasa dan nilai-nilainya sendiri, nilai-nilai nasional di mana anak bertempat tinggal, dari mana anak berasal, dan peradaban-peradaban yang berbeda-beda dari peradaban sendiri. Bagian yang sama pasal 59 disebutkan pemerintah dan lembaga negara lainnya berkewajiban dan bertanggung jawab untuk memberikan perlindungan khusus kepada anak dalam situasi darurat, anak yang berhadapan dengan hukum, anak dari kelompok minoritas dan terisolasi, anak tereksploitasi secara ekonomi an/atau seksual, anak yang diperdagangkan, anak yang menjadi korban penyalahgunaan narkotika, alkohol, psikotropika, dan zat adiktif lainnya (napza), anak korban penculikan, penjualan dan perdagangan, anak korban kekerasan baik fisik dan/atau mental, anak yang menyandang cacat, dan anak korban perlakuan salah dan penelantaran.

Undang-undang. ini terkadang menjadi momok tersenditi bagi pelaksana pendidikan khususnya pendidikan Islam. Beberapa kasus contohkan dalam dua tahun terakhir seorang guru Pesantran Modern harus berurusan di ranah hukum akibat melakukan kekerasan disaat menerapkan hukuman fisik dan nonfisik bagi pelanggar bahasa dan disiplin umum lainnya seperti keluar pesantren tanpa izin berkali-kali. Sehingga tanpa disengaja malayangkan tangan ketubuh anak didiknya. Artinya bahwa tidak semua hukuman untuk peserta didik dimaknai dengan kekerasan sebagaimana yang dipahami oleh masyarakat pada umumnya. Jika terjadi inseden yang tidak diinginkan pada saat pemberian hukum hal tersebut merupakan diluar kontrol seorang guru, maklum guru juga adalah manusia yang memiliki kekurangan dan kelebihan. Akan tetapi perlu diketahui bahwa tidak ada seorang guru yang waras yang mau menyakiti para muridnya kecuali adanya kelainan pada diri guru tersebut.

\section{E. Implikasi Teori Punishment Dalam dunia Pendidikan Islam}

Mengingat perkembangan masyarakat yang semakin lama terus mengalami pergeseran dari peradaban yang sesungguhnya maka, pumishment tidak diartikan sejuas kapasistas penganiayaan manusiawi. Punishment sesuangguhnya dalam dunia pendidikan dapat diartikan sebagai stimulus atau alat perangsang anak 
didik untuk mènuju pembaharuan serta pembiasaan yang jauh lebih baik dari sebelumnya. Punishment diperlukan mengingat peningkatan pelanggaran dalam berbagai dataran akademik untuk mengembalikan marwah peradaban bangsa dan agama. Punishment dalam dunia akdemik pada hakikatnya merupakan alat penggerak untuk mendisiplinkan peserta didik dari berbagai perilaku yang menderai identitas mereka sebagai peserta didik.

Perkembangan dunia pendidikan baik yang dipengaruhi langsüng oleh peradaban bangsa, media publik, pemimpin bangsa, dan pablik pigur akhir-akhir ini terus menyuntik generasi bangsa. Ironisnya virus ini terus menjangkit sampai lingkungan pendidikan, jika hal ini tidak dibendung dengan pemberian punishment yang berupa media kontrol maka virus ini akan terus menular sampai generasi tanpa batas usia. Punisbment dalam tiori pendidikan Islam merupakan media pendidikan yang disebut oleh Ramayulis sebagai media non material atau bahasa lainnya sebagai media pendidikan yang bukan benda. Sebagai media pendidikan yang bertujuan untuk dapat mengurangi pelanggaran serta memberikan' peringatan bagi indisipliner yang telah melampoi batas kewajaran.

Punishment dalam kajian pendidikan Islam diberikan tidak serta merta diberikan begitu saja. Langkah-langkah yang diberikan tidak langsung diberikan yang berupa punisbment yang berat namun adanya tahap-tahap yang nantinya diharapkan dapat mengubah anak yang indisipliner tersebut menjadi lebih baik. langkah-langkah tersebut dapat berupa memberikan bimbingan bagi yang pertama, memberikan teguran teguran bagi yang kedua kali, memberikan peringatan bagi yang ketiga, selanjutnya memberikan punishment yang mendidik baik yang berupa nonfisik yang diistilahkan hukuman sosial (mengambil sampah di lingkungan sekolah, membersihkan kamar mandi sekolah, dan lain-lain).

Pembetian hukuman ada tahapan yang harus diperhatikan oleh pendidik, mulai dari yang teringan hingga akhirnya menjadi yang terberat; yaitu: Memberikan nasehat dengan cara dan pada waktu yang tepat, yaitu dengan tidak memojokkan dan mengungkit-ungkit kekeliruannya dengan nasehat yang panjang lebar, karena dapat membuat anak menolak terlebih dahulu apa yang akan disampaikan. Pemilihan waktupun harus dipertimbangkan sehingga anak bisa enjoy menerima masukan. 
1. Hukuman pengabaian, untuk menumbuhkan perasaan tidak nyaman dan teracuhkan di hati anak.

2. Hukuman fisik, sebagai tahap akhir dengan catatan bahwa hukuman fisik (pukulan) yang diberikan tidaklah terlalu keras dan menyakitkan. ${ }^{13}$

Rasulullah Saw menjelaskan tahapan bagi pendidik untuk memperbaiki penyimpangan anak, mendidik, meluruskan kebengkokannya, membentuk moral dan spiritualnya menjadi tujuh seperti yang terdapat dalam buku Pendidikan Anak Dalam Islam, yaitu menunjukkan kesalahan dengan; pengarahan, tamah tamah, memberikan isyarat, kecaman, memutuskan hubungan (memboikotnya), memukul, dan memberi hukuman yang membuat jera. ${ }^{14}$ Berikut beberapa bentuk hukuman yang dapat dilakukan dalam lingkungan sekolah.

1. Nasehat dan bimbingan. Punishment yang berupa nasehat dan bimbingan cukup diperlukan dalam dunia pendidikan untuk itu seorang guru hendaknya tidak boleh bosan atau malas untuk memberikan nasehat dan bimbingan bagi para murid-muridnya. Perlu diingat bahwa memberikan nasehat dan bimbingan dalam dan luar sekolah diharuskan bagi siapa saja. Peranan triologi pendidikan sangat diharapkan dalam hal tersebut jangan menunggu pelanggaran terjadi apalagi sampai mengintai terjadinya pelanggaran terbut dilakukan oleh peserta didik kita semua. Peranan triologi pendidikan sangat diharapkan untuk dapat menasehati dan membimbing anak dalam kondisi bagaimanapun tanpa melihat siapa dan anak siapa. Guru bertanggung jawab dalam muapun Iuar sekolah, demikian halnya orang tua juga bertanggung jawab untuk tetap mengontrol anaknya di luar apa lagi di dalam rumah, dan masyarakat juga memiliki tanggung jawab pada peserta didik baik ketika berada di sekolah, di rumah apa lagi di luar rumah. Kedudukan triologi pendidikan harus sinerjik dalam berbagai hal, ketiganya memiliki garis koordinasi yang saling-silang antara satu dengan yang lain.

${ }^{13}$ Anonym, "again about feromot", dikutip dari http://insansalsabila.wordptess.com diunduh 31 Maret 2012.

${ }^{14}$ Abdullah Nasih Ulwan, Pendidikan Anak dalam Islam, terj. Jamaiudin Miri, Jakarta: Tp, 1994), hal. 316-323. 
Sehingga anak didik tetap terkontrol dan mendapatkan nasehat dan bimbingan dari kiri dan kanan sehingga pelanggaranpun akan semakin dipersempit oleh naschat dan bimbingan dari tokoh triologi pendidikan tersebut (orang tua, guru, dan masyarakat).

2. Kewibawaan dan khatismatik (taut wajah yang simpatik). Punisbment yang berikutnya dalam dunia pendidikan adalah pancaran aura kharismatik atau dalam dunia pendidikan disebut gezah. Punishment yang berupa pemancaran kharismatik yang diberikan oleh seorang guru merupakan hal yang dapat dilakukan, karena melalui wajah yang dihormati oleh peserta didik memberikan aura tersendiri bagi seorang anak untuk mereka ingat serta menjadi pablik pigur mereka dalam hidup. Setelah seorang guru, orang tua dan masyarakat menjadi pablik pigur bagi peserta didiknya sungguh mereka akan mudah menerima apapun yang nantinya diberikan oleh triologi pendidikan tersebut. Pablik pigur ini tidak dapat dibuat-buat atau direkayasa namun hal tersebut muncul karena faktor kepribadian tokoh tersebut, rumus yang dapat dilakukan adalah menyesuaikan diri dari perkataan dengan perbuatan.

3. Pendekatan Individual. Punishment melalui pendekatan individual ini merupakan pernberian punishment melalui perseorangan. Lembaga pendidikan merupakan instutusi yang memiliki sumber daya manusia yang terampil serta terdidik dalam berbagai bidaing disiplin ilmu. Disiplin ilmu tersebut sangat dibutuhkan oleh pata muridnya, pendekatan individu bertujuan untuk melakukan pengajian serta pendalaman terhadap kasus yang terjadi pada diri seorang indispliner dengan berabagi alasan atau latar belakang yang berbeda. Indisipliner yang dilakukan seorang anak dapat merupakan pegaruh dari dalam dirinya yang berupa kemelut jiwa katena kurang mendapatkan stimulus yang baik dari pembawaan hati dan akal yang kurang tenang alias tidak terkontrol dengan baik. $\mathrm{HaI}$ yang tidak pula kita nafikan terjadinnya indisipliner kerena pengaruh luar yang cukup meresahkan kita nyakni media elektronik dan catatan hidup figur bangsa yang mampu menerobos sendi-senidi dan saraf anak-anak sehingga eforbia percontohan terjadi di sana-sini. Punishment yang berupa pendekatan 
individual ini diharapkan dapat memberi langkah jitu untuk obat kebisaaan indisipliner anak selama ini. Pendekatan ini tentunya dapat memberikan peluang yang dinamis untuk lebih mengenal dan mengetahi karakter anak sehingga dapat memberikan masukan yang baik kepada anak tersebut.

4. Hukuman fisik yang terpaksa. Punishment yang berupa fisik menjadi pilihan terakhir yang dihapakan menjadi tolak ukur kesabaran kita dalam mendidik. Punishment yang berupa hukuman fisik merupakan langkah yang ditempuh di saat kondisi yang terpaksa dilakukan dalam dunia pendidikan. Namun sebenamya jauh dari hukuman fisik tersebut dilakukan petlu catatan yang harus diperhatikan oleh yang memberikan hukuman dalam hal ini adalah seorang guru. Memberikan hukuman fisik tidak mengandung unsur balas dendang atau sengaja memberikan karena bemiat untuk menjerakan bahkan sampai bertujuan untuk menyakiti anak. Pemberikan hukuman fisik diperlukan pertimbangan yang matang. serta rasa kasih sayang antara keduanya. Kasus-kasus yang acap kali terjadi dewasa ini adalah pemberian hukuman fisik disinyalir untuk menyakiti anak didik yang berdampak pada hubungan negatif atau hubungan yang tenggang antara keduanya sehingga sering anak menjadi lawan bagi para gurunya. Tips untuk mengatasi hal ini dapat berupa ketika hukuman fisik tersebut dilakukan oleh seorang guru hendaknya melakukan pendekatan lagi kepada indisipliner terbut sehinga anak tersebut tidak merasa dihukum atau di sakiti. Hal serupa yang dapat dicontohkan oleh Nabi Muhammad saw adalah ketika seseorang menghadapi anak dalam keadaan marah, maka hendaklah ia mengambiI wudhu', bila ia juga tidak sanggung menahan kemabarahnnya maka hendaklah ia masa istirahat dengan meninggalkan anaktersebut terelebih dahulu, jika kemarahannya sudah. mereda baru ia kembali untuk menghadapi anak terbut. Pengalaman yang diberikan oleh. Rasulullah tersebut merupakan metode yang tidak menginginkan terjadinya hukuman yang di luar alam sadar seorang guru dalam memberikan hukuman kepada anakanak.

Tindakan terkadang tidak dapat dipendam di saat pendidikan tersebut sedang kita laksanakan. Teori terkadang sulit dibawa dalam dunia praktis 
sehingga sering terjadi hal yang tidak diinginkan. Kesadaran dan kesiapkan kita bersama hari ini menjadi catatan serta pekerjaan rumah yang harus terselesaikan dengan segera, siap atau tidak kemelut ini sudah terjadi dalam lembaga pendidikan. Kesiapan diri menjadi kunci penegak serta senjata pamungkas yang harus dimiliki seorang guru. Untuk itu guru yang dibuhkan hari ini adalah bukan hanya guru yang cerdas intektualnya namuan juga cerdas emosional dan cerdaspula spritualnya. Integrasi ketiganya sangat dibutuhkan untuk menjadi guru yang tahu kebutuhan dan keinginan anak-anak. Mengingat gurí tidak hanya lahir dari dunia akademik yang menghabiskan waktu 3 atau 4 tahun seharusnya lebih membuka diri serta mencari pengalaman hidup di luar lembaga tersebut, karena kesiapan dan kesabaran akan muncul jika guru sudah banyak melihat dan mendalami duniä pendidikan sebelum berinteraksi langsung dengan anak-anak.

\section{F. Hak Asasi dalam Dunia Pendidikan Islam}

Hak asasi manusia dalam lingkungan pendidikan Islam menjadi hal penting untuk diperbincangkan agar ranah hukum serta publikasi perlu dipertimbangkan. Penjelasan hak asasi manusia dalam lembaga pendidikan perlu diperjelas dimaksudkan adalah dunia pendidikan berbeda dengan dunia public lepas lainnya. Kita harus dapat membedakan antara kekerasan, penganiayaan, dan pemberian hukuman, persepsi ini harus mampu dibedakan oleh penegak hukum tanpa dipolitisir oleh kepentingan kelompok atau individu. Pemberian hukuman yang dilakukan dalam dunia pendidikan baik hukuman nonfisik dan fisik dilakukan tentunya sudah banyak pertimbangan yang matang oleh praktisi pendidikan itu sendiri. Menjalankan pendidikan dengan kontekstual siswa dan sosial serta tantangan hidup tentu memerlukan batasan-batasan yang jelaš mana yang boleh dan mana yang tidak dibenarkan untuk dilakukan. Sorotan kekerasan di lembaga pendidikan hari ini jangan .sampai dinyalir dengan berbagai kepentingan baik orang tua sianak atau lembaga lainnya yang memiliki kepentingan.

Lembaga atau instansi pendidikan telah melakukan ijtihad yang kuat untuk terlaksananaya peraturan atau disipilin yang dimaksud untuk melakukan 
peningkatan dari berbagai bidang. Peningkatan tersebut pasti sangat sulit terwujudkan manakala situasi dan kondisi tidak memungkinkan tanpa adanya peraturan yang signifikan pula. Lembaga pendidikan asrama contohkan, adanya batasan-batasan yang berupa peraturan astama sebagai tolak ukur dan pembisaan anak agar menuju kebaikan ketika meranjak dewasa atau sampai mereka mampu memberdakan yang baik dan yang buruk. Sektor lainnya lainnya adalah lembaga pendidikan memiliki kurikulum, artinya batasan-batasan yang harus dijalani oleh peserta didiknya akan tetapi kurikulum tersebut akan sulit untuk terwujud bahkan dapat gagal, maka perlu petaturan yang mengikat anakanak agar kebiasaan baik tetap terimplikasi pada kehidupan mereka.

Kondisi di atas mengakomodir kebutuhan lembaga pendidikan untuk membutuhkan peraturan hukuman yang diberikan untuk memberikan arah yang - lebih baik pada peserta didik. Menjalankan punisbment tersebut tentuk tidak serta merta diberikan pada siswa tanpa aturan yang berlaku. Hak asasi manusia dalam hal ini adalah mereka berhak mendapatkan pelayanan yang baik. Pelayanan yang berupa pengajaran, pendidikan, dan pengembangan diri lainnya, dengan demikian untuk terlaksananya pelayanan tersebut perlu adanya peraturan yang disiapkan dan untuk terlaksananya peraturan perlu adanyanya stimulus yang menjadi media terlaksananya peraturan tersebut.

Insiden tiga tahun di lembaga pendidikan akhir-akhir ini menjadi pengingat bersama oleh semua lapisan elemen masyarakat yang mengelola lembaga pendidikan dan orang tua anak didik. Insiden yang terjadi di lembaga pendidikan yang melihat kronologi permsalahan setidaknya tidak dibawa hukum posistif yang nantinya akan membawa efek negatif terhadap perkembangan lembaga pendidikan itu sendiri. Ruang gerak serta kteativitas guru akan menjadi sempit karena harus beripikir dua kali jika berurusan dengan ranah hukum positif. Insiden yang dikronologikan terhadap pengembangan diri anak hendaknya diberikan tanah hukum tingkat satuan pendidikan itu sendiri bukan untuk dipublikasikan karena membawa efek yang panjang bagi perkembangan lembaga pendidikan itu sendiri. Namun tidak pula untuk menutupi kesalahan serta membiarkan kesalahan untuk kesekian kalinya. 
Hemat kita bersama yang hari ini terjadi dalam dunia pendidikan kita adalah banyaknya pendidik yang belum matang atau siap menjadi seorang pendidik, namun hanya siap untuk menjadi seorang pengar. Kematangan dan pesiapan inilah yang perlu dimatangkan oleh seorang pendidik yang professional, sosial dan kepribadian yang baik dalam dan luar lembaga pendidikan. Guru atau pendidik bukan hanya menjadi pendidik di dalam lingkungan sekolah namun mereka juga pendidik di luar sekolah. Hal yang sangat penting dikemukanan adalah jangan sesekali mengatakan jangan ke pada anak sedangkan kita sendiri melanggar kata tersebut dicontohkan seorang guru atau pendidikan melarang anak "jangan merokok", sedangkan guru tersebut sedang menghisap strutunya di depan atau di belakang murid-muridnya, maka disaat guru memberikan hukuman akan terjadi perasaan yang menentang dari jiwa seorang anak dengan sendirinya.

\section{G. Penutup}

Teori hukuman dalam perspektif pendidikan Islam memiliki versi masingmasing ada melarang adapula yang meperbolehkannya. Berbagai alasan serta situasi dan kondisi peserta didik dewasa ini hemat kita sudah harus berpikir positif terhadap pemberian hukuman kepada seorang anak. Pemberian hukuman tentunya didasari oleh alasan serta kondisi yang benar serta latar belakang yang tepat. Pemberian hulkuman di dalam dunia pendidikan setidaknya dapat diselesaikan dalam satuan pendidikan itu sendiri kecuali insiden tersebut tidak dapat diselesaikan oleh parktisi satuan pendidikan yang ada. Ranah hak asasi anak atau manusia hendaknya dapat membaca latar belakang insiden yang terjadi di sekolah atau lingkungan seolah katena hal tersebut akan dapat mempersempit ruang gerak guru untuk mengadakan perbaikan atau pemengambangan satuan pendidikan dan peserta didiknya. 
58 Millab Vol. XII, No.1, Agustus 2012

\section{DAFTAR PUSTAKA}

Ali, Abdullah. 1985. Kamus Istilah. Jakatta: Pustaka.

Depdikbud. 1998. Metodik Kbusus Program Pemberukan Perilaku di Taman Kanakkanak. Jakarta: Gramedia Widiasarana Indonesia.

Fauzan. 2011. Penerapan Hukuman Fïsik pada Dayab Syamsyuddhuba Cot Murong Kabupaten Aceb Utara. Medan: Tesis IAIN Medan Sumatera Utara.

Harianto, AJ. 1992. Pembinaan Pengurus Asrama Santri; Sebuab Proses Kaderisasi Kepemimpinan di Pondok Modem Gontor. Gontor: t.p.

- http://insansalsabila.wordpress.com.

Langeveld, M. J. Tt Beknotpte theoretische Paedagogik, Terj: I.P. Simanjuntak. Jakarta: Senat Mahasiswa Fakultas Imu Pendidikan IKIP.'

Ma'sa, Lukman bin. Konsep Pengbangaan dan Sanksi dalam pendidikan Islam (Studi Kasus Pendidikan pada Anak), http://www.google.com.

Munawwir, A.W., Tt. Kamus al-Munawwir Arab-Indonesia Terlengkap, Edisi Lux.

Rasyidin, Al. 2008. Falsafab Pendidikan Islami; Membangun Kerangka Ontologi. Epistimologi, dan Aksiologi Praktik Pendidikan. Bandung; Citapustaka.

Sastrapraja, M. Tt. Kamus Istilab Pendidikan dain Umum untuk, Guru, Calon Guru dan Umum. Surabaya: Usaha Nasional.

Sina, Ibn. 2001. "Tis'u Rasail" dalam Abuddin Nata, Pemikiran Para Tokoh Pendidikan Islam. Jakarta: Raja Grafindo Persada. .

Ulwan, Abdullah Nasih. 1994. Pendidikan Anak dalam Islam. Terj. Jamaiudin Miri. Jakarta: Tp.

www.bookfinder.com/dir/i/Undang-Undang_HAM_1999-UU_RI_No_39. 